\title{
ОЦІНКА ОСНОВНИХ ПОКАЗНИКІВ КОМБІНОВАНОГО ВИРОБНИЦТВА ЕЛЕКТРИЧНОЇ ЕНЕРГІЇ ТА ТЕПЛОТИ НА ПАРОТУРБННИХ УСТАНОВКАХ АТОМНИХ ЕЛЕКТРИЧНИХ СТАНЦІЙ
}

Дубовський С.В., докт. техн. наук, Хортова О.О.

Інститут технічної теплофізики НАН Украӥни, вул. Желябова, 2а, Київ, 03680, Україна

Наведено теоретичні особливості розрахунку питомих витрат палива на відпуск електричної та теплової енергії від паротурбінних установок атомних електричних станцій термодинамічним методом. Представлено емпіричну залежність основних показників енергетичної ефективності таких установок від початкових та кінцевих параметрів робочого процесу.
Приведены теоретические особенности расчета удельных рас- calculation of the specific expenses ходов топлива на отпуск элек- of fuel on electric and heat energy трической и тепловой энергии supply by thermodynamic method от паротурбинных установок are adduced for the steam turbines of атомных электростанций термо- nuclear power plants. The empirical динамическим методом. Представ- dependence of the main indicators of лена эмпирическая зависимость the energy efficiency of such plants on основных показателей энергети- the initial and final parameters of the ческой эффективности таких working process is presented. установок от начальных и конечных параметров рабочего процесса.

Библ. 17, табл. 3, рис. 2.

Ключові слова: атомна електрична станція, розподіл витрат палива, питомі витрати палива на електростанціях, методи розподілу, термодинамічний метод.

$b_{e}$ - питома витрата умовного палива на відпущену електроенергію, г у.п./кВт·год;

$b_{T}$ - питома витрата умовного палива на відпущену теплову енергію, кг у.п./ГДж (кг у.п./ Гкал);

$E_{\text {відn }}$ - фактичний відпуск електроенергії від енергоблоку, ГДж (Гкал);

$N_{\text {ном }}$ - номінальна потужність турбоустановки у конденсаційному режимі, МВт;

$Q$ - фактичні витрати теплоти на паротурбінну установку AEC, ГДж (Гкал);

$Q_{\text {вiдn }}$ - фактичний відпуск теплової енергії, ГДж (Гкал);

$Q_{e}$ - витрата теплоти на відпущену електроенергію, ГДж (Гкал);

$Q_{p}$ - виробіток первинної теплоти активною зоною реактора за відповідний проміжок часу, тис.ГДж;

Атомні електричні станції є одним з основних генеруючих джерел електроенергії України, частка яких від загального виробітку за останнє
$Q_{T}$ - витрата теплоти на відпущену теплову енергію, ГДж (Гкал);

$q_{e}$ - питома витрата теплоти на відпущену електроенергію, кДж/кВт·год (ккал/кВт·год);

$q_{T}$ - питома витрата теплоти на відпущену теплову енергію, кДж/ГДж (ккал/ккал);

$t_{a}$ - температура оточення, ${ }^{0} \mathrm{C}$;

$\omega$ - усереднений коефіцієнт термодинамічної цінності теплоти;

АЕC - атомна електрична станція;

ККД - коефіцієнт корисної дії;

КТЦ - усереднений коефіцієнт термодинамічної цінності теплоти;

ТЕС - теплова електрична станція;

ТЕЦ - теплоелектроцентраль;

ЦВТ - циліндр високого тиску;

ЦНТ - циліндр низького тиску;

ЦСТ - циліндр середнього тиску.

десятиріччя складає близько 48 \%. Поряд з виробництвом електричної енергії АЕС відпускають також теплоту 3 відборів турбін для потреб 
міст-супутників у кількості до 2 \% від відпуску електричної енергії. На сьогодні в Україні діє 4 атомні електростанції з 15 енергоблоками загальною встановленою потужністю $13800 \mathrm{MBT}$, на яких встановлені енергоблоки з реакторами типів BВEР-1000 і ВВЕР-440 та паротурбінними установками на насиченій парі. Згідно проектних характеристик найпоширеніших серійних парових турбін для АEC, що наведені в [1], вони здатні відпускати у кілька разів більшу кількість теплоти для потреб зовнішнього теплопостачання.

Але в силу багатьох причин, однією 3 яких $€$ віддаленість АЕС від крупних міст потенційних споживачів теплової енергії, системи теплофікаційного теплопостачання на базі ядерного палива розвитку на Україні не одержали, незважаючи на існування подібних проектів ще у 70-ті роки минулого століття. Разом з тим, можливість значної економії газомазутного палива, що зазвичай використовується теплоджерелами систем централізованого теплопостачання міст, зниження викидів продуктів їх згоряння в місцях концентрації населення, зниження тарифів на теплоту внаслідок заміщення природного газу на значно більш дешеве ядерне паливо робить задачу суттєво більшого привернення атомних електростанцій для подальшого розвитку теплофікації дедалі актуальнішою.

Позитивний досвід теплофікації міст від АЕС існує, зокрема, у Швейцарії і Словаччині. Швейцарська АЕС «Безнау» ще з 1985 року здійснює централізоване теплопостачання 11 населених пунктів тепловою мережею протяжністю 137 км у двотрубному обчисленні, 3 них магістральних теплопроводів - понад 35 км. Діюча АЕC «Богуніце» у Словаччині з 1985 і 1997 рр. постачає теплову енергію для декількох міст, розташованих на відстані 10..15 км один від одного [2]. Проекти дальнього транспорту теплоти від АЕС на відстань 55...75 км розглядаються у Фінляндії (АЕС «Ловііза», 2009 р.), в Україні (Запорізька AEC, 2006 р.), в Росії [2].

Поряд із цим, альтернативу таким проектам можуть скласти місцеві джерела теплоти на органічному паливі, системи електричного опалення від АЕС, особливо, на основі використання теплових насосів $з$ електроприводом, здійснення яких позбавляє необхідності використання про- тяжних теплових мереж і забезпечує можливість регулювання електричної потужності АЕС. Зрозуміло, що поряд із технічними і практичними чинниками, притаманними відповідним концептуальним рішенням, кінцевим критерієм їх зіставлення $є$ вартість відпуску теплоти кінцевим споживачам. Для місцевих джерел теплоти на органічному паливі та/або електричній енергії цей показник визначається, головним чином, умовно змінною складовою виробничої вартості, що майже цілком обумовлюється витратами на паливо, а для АЕС більш важливою $є$ умовно постійна (непаливна) складова. До того ж, у разі дальнього транспорту, слід враховувати значні капітальні витрати на спорудження магістральної теплотраси, додаткові витрати електричної енергії на транспорт теплоти та iї транспортні втрати. Тому навіть в умовах відносно дешевого ядерного палива, тариф на відпуск теплоти від АЕC може бути більшим, ніж місцевих теплоджерел. Так, за даними [2], відпускний тариф для споживачів теплоти від згаданої вище АEC швейцарської «Безнау», становить у середньому, 0,08 франків/ кВт·год, від місцевих котелень на органічному паливі - 0,05 до 0,09 франків/кВт·год, а від теплових насосів - 0,05 франків/кВт год. 3 цього випливає, що для забезпечення конкурентних переваг теплопостачання від ядерних джерел, рівень питомої витрати палива на відпуск теплоти від AEC повинен бути якомога нижчим порівняно 3 місцевими джерелами теплоти. Згідно даних [3], розрахункові значення питомої витрати умовного палива на відпуск теплоти від АЕС України у місцеві мережі є зіставними з відповідними показниками котельних на природному газі і вищими за відповідні показники сучасних ТЕЦ. Однак є підстави вважати, що таке положення визначається насправді завищенням витрат АЕC на відпуск теплоти, обумовленим методичними недоліками їх обчислення.

Звітні показники питомих витрат первинної теплоти на відпуск електричної та теплової енергії АЕС визначають згідно статистичної звітності за формою 3-ТЕК (АЕС), чинної з 1987 року, використовуючи так званий фізичний метод. Для забезпечення наочного співставлення $\mathrm{AEC} 3$ іншими енергетичними установками 3 виробництва електричної енергії та теплоти, у [3] 
пропонується виражати теплоту, що виділяється у реакторі енергоблоку АЕС у одиницях умовного палива $(1$ т у.п. $=7$ Гкал $=8,147$ МВт.год = 29,3076 ГДж). Фізичний метод був прийнятий у якості галузевого стандарту електроенергетики у 50-ті роки, незважаючи на справедливі зауваження щодо порушення ним законів термодинаміки 3 метою зниження звітних значень питомої витрати палива на відпуск електричної енергії від електричних станцій енергетичної системи за рахунок віднесення економії палива внаслідок комбінованого виробництва тільки на електричну енергію [4]. Зворотнім боком цього виявилося згодом штучне збільшення витрат палива на відпуск теплоти, яке поставило більшість ТЕЦ i TЕС комбінованого виробництва в невигідні умови. Тому, галузевий стандарт України [5], що продовжив дію «фізичного» методу у 1996 році, невдовзі був доповнений новим стандартом [6] чинним з 1998 року, який декларував принцип рівного поділу економії палива між обома видами продукції ТЕЦ. Крім того, у 2003 році у галузі був прийнятий новий стандарт, який дозволяв електричним станціям визначати коефіцієнти поділу економії палива між видами продукції на власний розсуд [7]. Поряд з цим зазначеним документом регламентуються термодинамічно обумовлені значення коефіцієнту поділу, розроблені авторами цієї роботи. Вони використовуються у якості граничних значень цього коефіцієнту.

На сьогодні в Україні використовуються всі три зазначені стандарти. Стандарт [5] прийнятий більшістю ТЕС генеруючих компаній і локальних (блокових) ТЕС. Більшість ТЕЦ загального користування використовує стандарт [6]. Стандарт [7] 3 термодинамічними коефіцієнтами поділу використовують окремі ТЕС генеруючих компаній. Таким чином, єдиний підхід щодо визначення i зіставлення між собою джерел виробництва теплоти на органічному паливі, електричній та ядерній енергії фактично не встановлений, хоча насправді він існує і визначається загальними фізичними законами. Основні положення єдиного термодинамічного підходу до визначення показників теплової економічності виробництва електричної енергії та теплоти комбінованим методом докладно описані в літературі [8 - 9]. Його основу становить закон збереження і пере- творення механічної енергії, згідно якого максимально можлива робота (ексергія) робочого тіла силової установки перетворюється у електричну енергію та теплоту втрат роботи в еквівалентних кількостях. Поряд з законом збереження теплоти процесу комбінованого виробництва цей принцип дає загальне рішення задачі поділу витрат між продуктами комбінованого виробництва, яке повністю узгоджується 3 обома законами термодинаміки.

В даній роботі розглянуті загальні особливості розрахунку показників енергетичної ефективності паротурбінних установок АЕС термодинамічним методом, підтверджуючи на прикладі перевагу його використання як базису для оцінювання основних показників таких установок.

Згідно з термодинамічним методом [8 - 9] витрати теплоти на відпуск електричної та теплової енергії від паротурбінної установки АЕС визначаються за формулами:

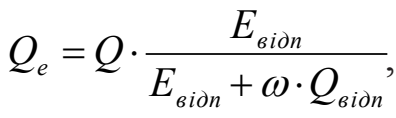

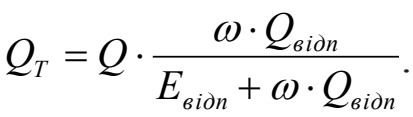

Відповідні питомі витрати теплоти на відпуск електричної та теплової енергії визначені відношеннями:

$$
\begin{gathered}
q_{e}=\frac{Q_{e}}{E_{\text {вidn }}}, \\
q_{T}=\frac{Q_{T}}{Q_{\text {sidn }}} .
\end{gathered}
$$

Загальна витрата теплоти $Q$ та фактичні відпуски електричної енергії $E_{\text {відn }}$ та теплової енергії $Q_{\text {відn }}$ (у формулах (1), (2) вони надаються у однакових фізичних одиницях виміру) відносяться до параметрів зовнішнього або комерційного обліку і припускаються відомими.

Усереднений коефіцієнт термодинамічної цінності теплоти представляє собою відношення питомих витрат первинної теплоти:

$$
\omega=\frac{q_{T}}{q_{e}} .
$$

За своєю фізичною сутністю КТЦ враховує як температурний потенціал теплоти, що відпус- 
кається, так і невідновні втрати, що супроводжують процес перетворення енергії у iï корисні види. В ідеальному випадку (відсутність втрат) КТЦ збігається з ексергетичною температурною функцією теплоти.

Для аналізу існуючих електростанцій, щодо яких відомі основні звітні показники за чинними формами статистичної звітності, існує можливість спрощеного визначення КТЦ електростанції у цілому за формулою:

$$
\omega=\frac{\eta_{0}-\eta_{e}}{1-\eta_{e}}
$$

де $\eta_{e}=\frac{E_{\text {sidn }}}{Q_{p}}-$ фактичний електричний ККД нетто; $\eta_{0}-$ теоретичний коефіцієнт корисної діï, що визначає граничну ефективність виробництва електричної енергії за умови ідеального ізоентропійного розширення робочого тіла до температури оточуючого середовища та відсутності втрат теплоти.

Формула (6) носить універсальний характер, але визначення іiі правої частини потребує врахування термодинамічних особливостей роботи конкретних установок. ККД теоретичного циклу Ренкіна $\eta_{0}$, знання якого необхідне для обчислення КТЦ, визначається типом і параметрами теоретичного циклу паротурбінної установки.

В основі роботи паротурбінних установок на насиченій парі, які використовуються на всіх АЕC 3 реакторами типу ВBEР, лежить термодинамічний цикл Ренкіна 3 проміжною сепарацією та перегрівом пари у сепараторіпароперегрівнику [10-11]. Схематичне зображен- ня зазначеного термодинамічного циклу в [h-s]діаграмі наведено на рис. 1.

Для турбін насиченої пари атомних електростанцій, [h-s]-діаграма якого представлена на рис. 1, ККД теоретичного циклу можна визначити за відомими початковими та кінцевими параметрами робочого тіла за формулою:

$$
\eta_{0}=\frac{\left(h_{0}-h_{o c a}\right)+X_{o c} \cdot\left(h_{n n}-h_{k a}\right)}{h_{0}-h_{\text {жв }}} .
$$

Залежність ККД теоретичного циклу Ренкіна від зміни температури оточення для найпоширеніших діючих турбоустановок АЕС [1], яку одержано за формулою (7), наведено на рис. 2.

Як видно з рис. 2, залежності ККД теоретичного циклу від температури оточення для паротурбінних установок АЕС підпорядковуються лінійному закону:

$\eta_{0}=\frac{\eta_{0}^{0}-a \cdot t_{a}}{100}$.

Постійні коефіцієнти у цій формулі розраховані за даними типових установок АЕC i наведені в табл. 1.

Слід зазначити, що значення температури оточення, внаслідок фактичного температурного розшарування природних масивів грунту, атмосферного та водного басейнів тощо, саме по собі $\epsilon$ певною мірою непевним. Сдиною умовою для iіi визначення $\epsilon$ нульова корисність теплоти для прямого теплоспоживання. За такий рівень, як це прийнято у теплотехніці, логічно прийняти у якості базової температуру $0{ }^{\circ} \mathrm{C}$, яка визначає нульовий рівень ентальпії та ексергії

Табл. 1. Коефіцієнти залежності ККД теоретичного циклу від температури оточення для типових турбоустановок АЕС з реакторами типу ВВЕР

\begin{tabular}{|l|c|c|c|c|c|}
\hline \multirow{2}{*}{$\begin{array}{c}\text { Найменування, } \\
\text { розмірність }\end{array}$} & \multicolumn{5}{|c|}{ Кип турбоустановки } \\
\cline { 2 - 6 } & К-220-4-1 & К-220-4-4 & $\begin{array}{c}\text { К-500- } \\
60 / 1500\end{array}$ & $\begin{array}{c}\text { К-1000- } \\
60 / 1500-1\end{array}$ & $\begin{array}{c}\text { К-1000- } \\
60 / 1500-2\end{array}$ \\
\hline Завод-виготовлювач & ХТ3 & ХТ3 & ХТ3 & ХТ3 & ХТ3 \\
\hline $\begin{array}{l}\text { Граничний ККД } \\
\text { турбоустановки, } \eta_{0}^{0}, \%\end{array}$ & 41,762 & 41,769 & 43,048 & 43,048 & 43,048 \\
\hline $\begin{array}{l}\text { Коефіціснт } \\
\text { температурної } \\
\text { залежності, } a, \% /{ }^{\circ} \mathrm{C}\end{array}$ & 0,1636 & 0,1608 & 0,1541 & 0,1541 & 0,1541 \\
\hline
\end{tabular}


теплоти. Якщо виникає необхідність уточнення показників ефективності, наприклад, 3 метою їх порівняння у різні періоди роботи однієї ж тієї установки з різними температурами оточення, це можна зробити за формулою (8) з урахуванням даних табл. 1.

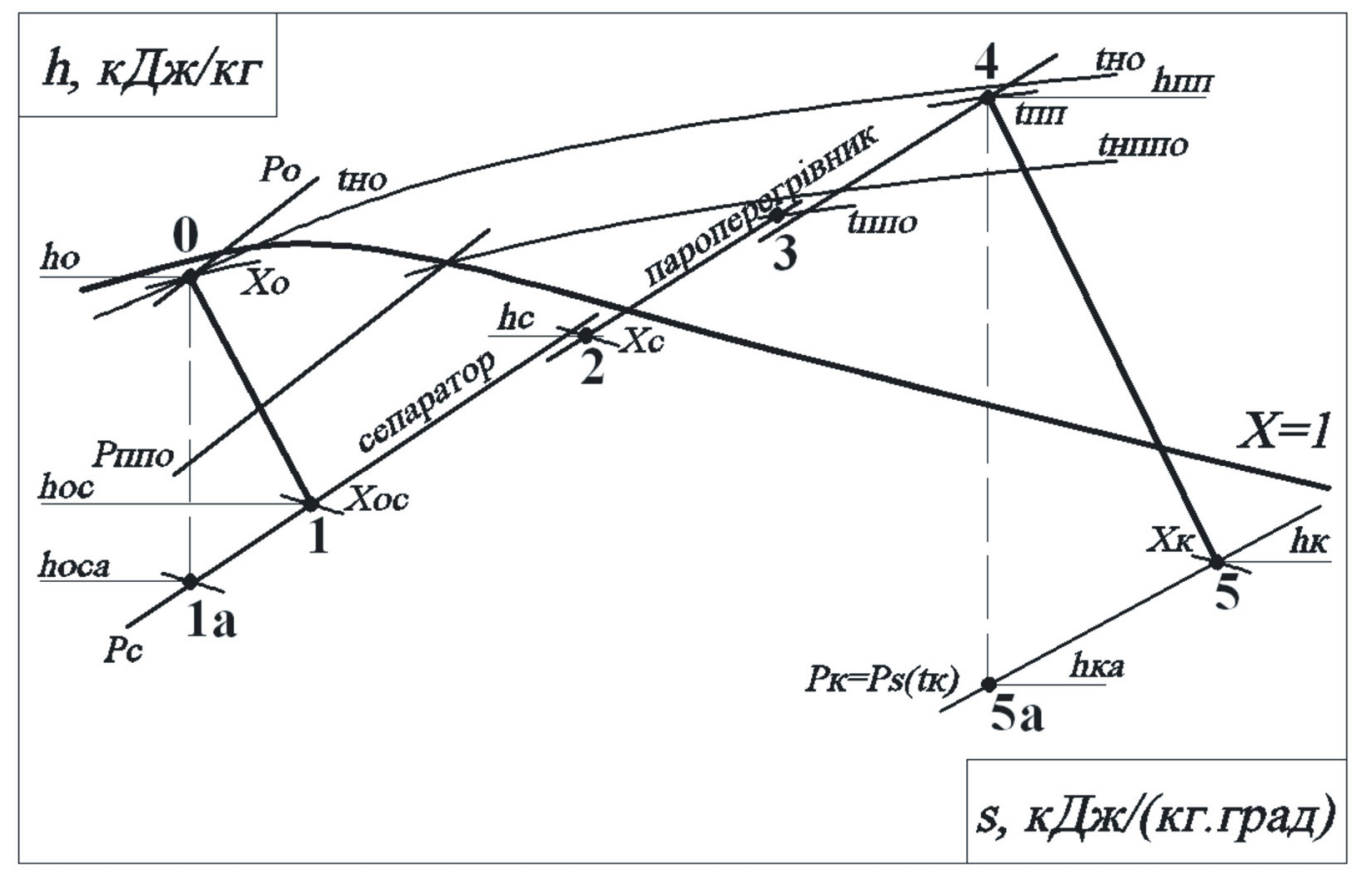

Рис. 1. Тепловий процес турбіни на насиченій водяній парі з використанням сепарації вологи та проміжннго перегріву відбірною та свіжюю парою в [h-s]-діаграмі:

0 - теоретична точка початку адіабатичного процесу розширення пари в турбіні;

1а-теоретична точка кінця адіабатичного процесу розиирення пари в ЦВТ турбіни;

1 - фактична точка кінця процесу розширення пари в ЦВТ турбіни

(точка початку процесу підсушки вологої пари в сепараторі);

2 - фактична точка кінця процесу підсушки пари в сепараторі;

3 - фактична точка початку процесу проміжного перегріву пари в пароперегрівнику відбірною і свіжюю парою;

4 - теоретична точка початку адіабатичного процесу розширення пари в ЦСТ ЦНТ турбіни; 5 -теоретична точка кінця адіабатичного процесу розширення пари в ЦНТ турбіни;

5 - фактична точка кінця процесу розширення пари в ЦНТ турбіни;

$P_{0}, t_{н 0}, X_{\theta} h_{0}$ - тиск, температура насичення, вологість та ентальпія свіжсї пари; $\boldsymbol{P}_{c}-$ тиск пари в сепараторі;

$X_{o c}, h_{\text {ос }}$ - вологість та ентальпія відпрацьованої в ЦВТ турбіни вологої пари, що поступає в сепаратор;

$X_{c} h_{c}$-вологість та ентальпія підсушеної пари на виході з сепаратору;

$P_{n п}-$ тиск пари, яка відбирається на жсилення проміжного пароперегрівника відбірної пари;

$t_{\text {по }}$ - температура пари на виході з проміжного пароперегрівника, щцо жсивиться відбірною парою;

$t_{n n}, h_{n n}$ - температура та ентальпія пари на виході з проміжного пароперегрівника, щц живиться свінсою парою;

$P_{\kappa}-$ тиск пари в кінці процесу розширення турбіни;

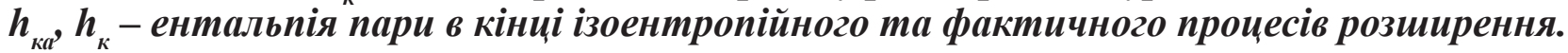




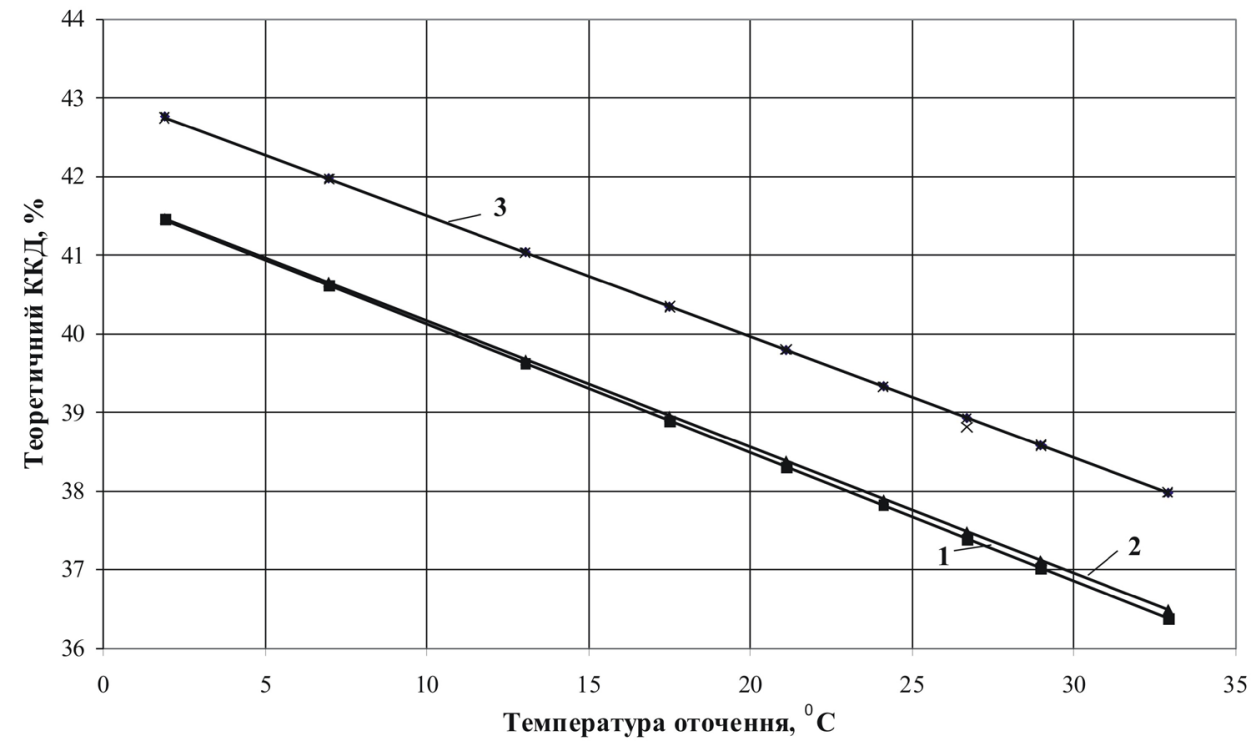

Рис. 2. Залежність ККД теоретичного циклу паротурбінних установок АЕС від температури оточення:

1- турбоустановка типу K-220-4-1; 2 - турбоустановка типу K-220-4-4; 3 - турбоустановки типу К-500-60/1500, K-1000-60/1500-1, K-1000-60/1500-2.

Табл. 2. Питомі показники роботи АЕС з реактором ВВЕР-1000 за 2006 рік

\begin{tabular}{|c|c|c|c|c|c|c|c|c|}
\hline \multirow{2}{*}{\multicolumn{2}{|c|}{$\begin{array}{c}\text { Період } \\
2006 \text { року }\end{array}$}} & \multicolumn{2}{|c|}{$\begin{array}{c}\text { Питомі витрати } \\
\text { умовного палива } \\
\text { за даними [4] }\end{array}$} & \multirow{3}{*}{$\begin{array}{c}\text { Середній } \\
\text { коефіцієнт } \\
\text { термодинамічної } \\
\text { цінності } \\
\\
\\
\omega \\
\\
0,2493\end{array}$} & \multicolumn{2}{|c|}{$\begin{array}{c}\text { Питомі витрати } \\
\text { умовного палива } \\
\text { за термодинамічним } \\
\text { методом } \\
\end{array}$} & \multicolumn{2}{|c|}{$\begin{array}{c}\text { Виробництво } \\
\text { первинної } \\
\text { теплоти }\end{array}$} \\
\hline & & † & 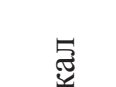 & & t్ర & 氕 & 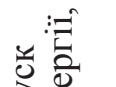 & \\
\hline 1 & січень & 508,9 & 0 & & 508,9 & 0 & 100,0 & 0,0 \\
\hline 2 & лютий & 423,6 & 163,1 & 0,2015 & 427,3 & 100,1 & 98,9 & 1,1 \\
\hline 3 & березень & 415,0 & 148,9 & 0,1958 & 419,5 & 95,5 & 98,6 & 1,4 \\
\hline 4 & квітень & 391,7 & 154,4 & 0,1769 & 397,3 & 81,8 & 98,2 & 1,8 \\
\hline 5 & травень & 395,1 & 167,6 & 0,1760 & 397,1 & 81,3 & 99,3 & 0,7 \\
\hline 6 & червень & 404,0 & 155,4 & 0,1837 & 405,7 & 86,7 & 99,4 & 0,6 \\
\hline 7 & липень & 450,0 & 158,0 & 0,2216 & 455,2 & 117,3 & 98,3 & 1,7 \\
\hline 8 & серпень & 459,1 & 148,3 & 0,2249 & 461,7 & 120,8 & 99,1 & 0,9 \\
\hline 9 & вересень & 432,6 & 0 & 0,2046 & 432,6 & 0 & 100,0 & 0,0 \\
\hline 10 & жовтень & 450,4 & 164,4 & 0,2189 & 452,6 & 115,2 & 99,3 & 0,7 \\
\hline 11 & листопад & 467,7 & 157,4 & 0,2322 & 473,4 & 127,8 & 98,3 & 1,7 \\
\hline 12 & грудень & 432,3 & 163,4 & 0,2089 & 437,1 & 106,2 & 98,6 & 1,4 \\
\hline
\end{tabular}


Табл. 3. Питомі показники роботи АЕС з реактором ВВЕР-440 за 2006 рік

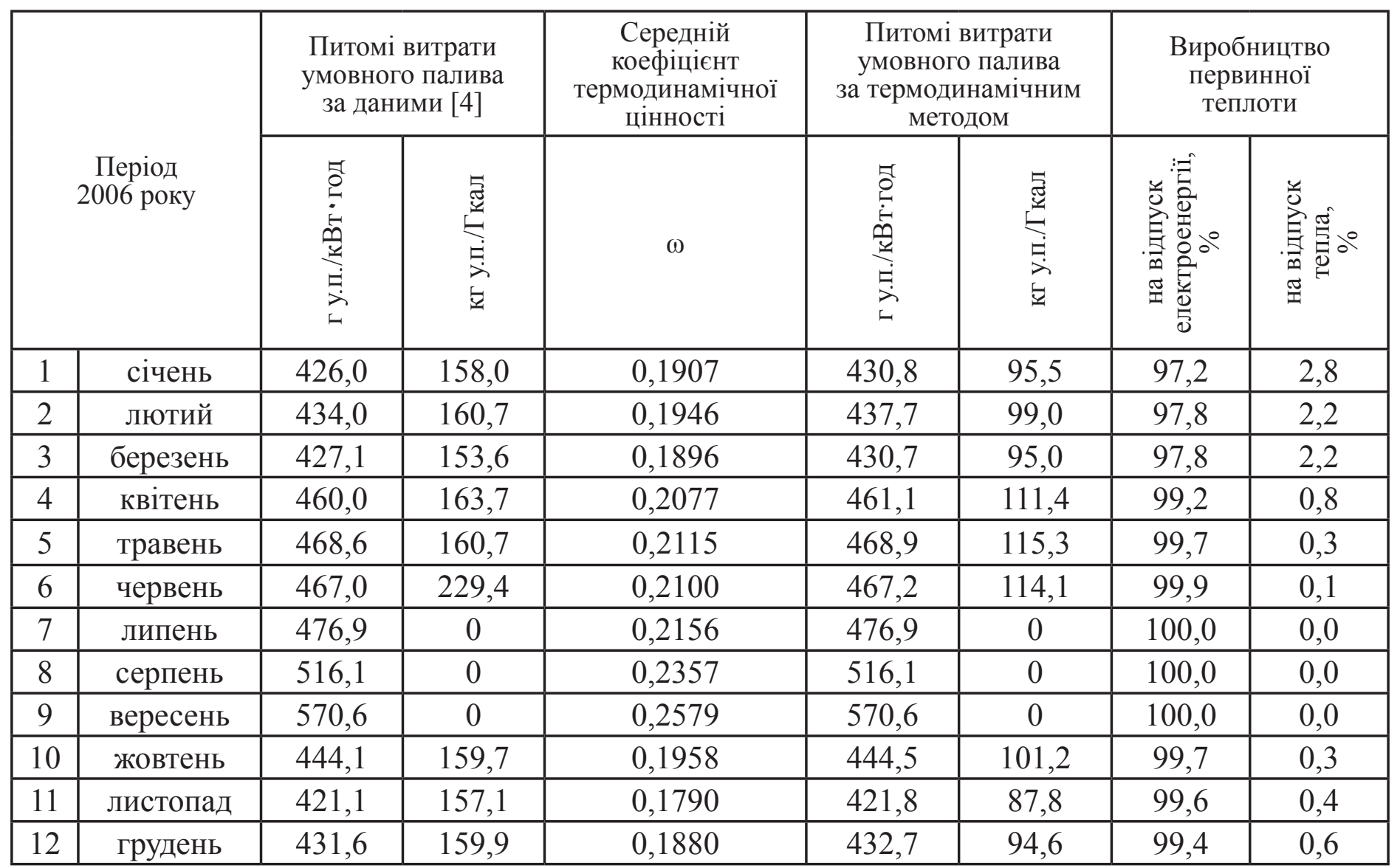

Порівняльні оцінки значень питомої витрати умовного палива на відпуск теплової та електричної енергії від АЕС за термодинамічним методом виконувалися 3 використанням даних роботи [3], де представлені основні середньомісячні звітні показники роботи енергоблоків AЕC з реактором типу ВВЕР-1000 та ВВEР-440 за календарний рік. Результати розрахунків порівняно із відповідними звітними даними енергоблоків по місяцях 2006 року наведено у табл. 1 та табл. 2 (температура оточуючого середовища приймалась $0{ }^{\circ} \mathrm{C}$ ).

3 наведених даних можна бачити, що питомі витрати умовного палива на відпуск електричної енергії від АЕС 3 реактором ВВЕР-1000 та ВВЕР-440, що розраховані за термодинамічним методом, незначно збільшені порівняно 3 даними за методикою [3], що пояснюється незначним обсягом відпуску теплоти 3 частково відпрацьованою парою, порівняно з загальним відпуском електричної енергії.

Одержані дані показують, що звітні показники АЕС $з$ відпуску теплоти є зіставними 3 відповідними показниками газових котелень систем централізованого теплопостачання великої потужності, які складають на сьогодні близько 154 кг/Гкал. Судячи 3 цього, розглянуті AEC практично не мають необхідного запасу ефективності перед котельними, який зміг би компенсувати втрати на дальній транспорт теплоти.

В той же час, термодинамічно обумовлені значення питомої витрати палива на відпуск теплової енергії $є$ значно нижчими, що обумовлює значну перевагу теплопостачання від AEC порівняно з газовими котельнями, дозволяє вести мову не тільки про економічну, але й про енергетичну доцільність дальних систем теплопостачання від AEC із заміщенням існуючих теплових джерел на базі газифікованих котелень. 


\section{Висновки}

1. Розглянуто особливості розрахунку показників теплової економічності комбінованого виробництва електричної енергії та теплоти енергоблоком AEC на насиченій парі термодинамічним методом, що відображає фізичну сутність процесів перетворення енергії в їі паротурбінних установках.

2. Визначено залежність теоретичного ККД термодинамічного циклу АЕС насиченої пари від початкових і кінцевих параметрів пари, що дозволяє виконувати розрахунки показників теплової економічності енергоблоків AEC за стандартними формами статистичної звітності.

3. Проведені порівняльні розрахунки середньомісячних значень питомої витрати умовного палива на відпуск електричної енергії та теплоти за чинним «фізичним» методом і за термодинамічним методом.

4. Обгрунтовано необхідність і доцільність впровадження нової методики для визначення витрат палива (теплоти) на відпуск електричної та теплової енергії на атомних електростанціях на базі термодинамічного методу. Встановлено, що питома витрата палива на відпуск теплоти енергоблоками АЕС є значно нижчою за відповідні показники найбільш ефективних газових котелень, що обумовлює енергетичну доцільність дальнього транспорту теплоти від AEC.

5. Коректне визначення та аналіз показників енергетичної ефективності 3 використанням розробленого термодинамічного підходу дозволяє надалі вирішувати задачі щодо найвигідніших схем реалізації теплопостачання.

\section{ЛІТЕРАТУРА}

1. Трояновский Б. М., Филиппов Г. А., Булкин $A$. E. Паровые и газовые турбины атомных электрических станций. - М.: Энергоатомиздат, 1985. -256 c.
2. Пузаков B. C. Европейский опыт организации теплоснабжения от АЭС // Новости теплоснабжения. - 2011. - № 2. - С. 49-56.

3. Ватагин М. Ю. Способ эквивалентного сравнения первичной теплоты и полезной энергии при производстве на АЭС (СЭСТЭ-АЭС) // Енергетика та електрифікація. - 2009. - №8. - С. 3-20.

4. Bonросы оценки эффективности ТЭЦ / Под ред. Винтера А. В. - М.-Л.: Госэнергоиздат, 1956.

5. ГКД 34.09.103-96. Расчет отчетных технико-экономических показателей электростанции о тепловой экономичности оборудования. Методические указания. - К.: УНИО Энергопрогресс, 1996. $-137 \mathrm{c}$.

6. ГКД 34.09.108-98. Розподіл витрат палива на теплових електростанціях на відпущену електричну і теплову енергію при їх комбінованому виробництві. Методика. - К.: НДІ Енергетики, 1998. - 17 c.

7. ГКД 34.09.100-2003. Витрати палива на відпущену електричну та теплову енергію при їх комбінованому виробництві на теплових електростанціях. Методика визначення. - К. : ОЕП «ГРІФРЕ», 2003. - 25 с.

8. Дубовской C. В. Термодинамический метод разделения затрат в комбинированных энергетических процессах // Промышленная теплотехника. - 1995. - Т. 17, № 1-3. - С. 85-92.

9. Дубовской С. В. Достоверность методов оценки показателей тепловой экономичности ТЭС с комбинированным производством электрической и тепловой энергии // Проблеми загальної енергетики. - 2001. - № 5. - С. 33-41.

10. Маргулова T. Х. Атомные электрические станции: Учебник для вузов. - М.: Высш. школа, 1978. - $360 \mathrm{c.}$.

11. Рыжкин В. Я. Тепловые электрические станции: Учебник для вузов / Под ред. В.Я. Гиршвельда. -М.: Энергоатомиздат, 1987. - 328 с. 


\section{ASSESSMENT OF BASIC INDICATORS OF THE COMBINED HEAT AND ELECTRIC ENERGY GENERATION ON THE STEAM TURBINES OF THE NUCLEAR POWER STATIONS}

\section{Dubovskoy S.V., Khortova O.A.}

Institute of Engineering Thermophysics National Academy of Sciences of Ukraine, vul. Zhelyabova, 2a, Kyiv, 03680, Ukraine

The theoretical features of calculation of the specific fuel expenditures on heat and electric energy supply by thermodynamic method are adduced for the steam turbines of the nuclear power station. The empirical dependence of the main indicators of the energy efficiency of such plants on the initial and final parameters of the working process is presented.

References 17, tables 3, figures 2.

Key words: nuclear power station, distribution of fuel expenditures, specific fuel expenditures at power plants, distribution methods, thermodynamic method.

1. Troyanovskyy B.M., Fylyppov G.A., Bulkin $A$.E. Steam and gas turbines nuclear power stations. - M .: Energoatomizdat, 1985. - 256 p. (Rus.)

2. Puzakov V.S. Europe experience of the heat supply organization from nuclear power plant // News teplosnabzhenyya. - 2011. - № 2. - P. 49-56. (Rus.)

3. Vatahyn M. Method of the equivalent compared of the primary heat and usable energy in production at the nuclear power plant // Energy and Electrification. - 2009. - №8. - P. 3-20. (Rus.)

4. The questions to assess the effectiveness of CHP / pod. red. Winter A.V. - M.- L .: Gosenergoizdat 1956. (Rus.)

5. GKD 34.09.103-96. Calculation of reporting technical and economic indicators of the power plant thermal efficiency of the equipment. Methodical specified. - K .: UNYO Energoprogress, 1996. - 137 p. (Rus.)

6. GKD 34.09.108-98. Distribution of fuel consumption for thermal power supplied to the electric and thermal energy in their combined production. Methods. - K .: NDI Enerhetyky, 1998. -17 p. (Rus.)

7. GKD 34.09.100-2003. The fuel expenditures for supplied to the electric and thermal energy in their combined production by thermal power station. The methods of evaluation. - K .: OEP "GRIFRE", 2003 - 25 p. (Ukr.)

8. Dubovskoy $S$. V. Thermodynamic method of the distribution fuel expenditures in combined energy process. // Industrial Heat Engineering. - 1995. - Vol 17, № 1-3. - P. 85-92. (Rus.)

9. Dubovskoy $S$. V. Reliability of estimation methods of thermal profitability for power station with the combined heat and power generation // The Problems of General Energy. - 2001. - № 5. - P. 33-41. (Rus.)

10. Marhulova T. H. Nuclear power stations: Textbook for Universities. - M.: Vyshaya shkola, 1978. - 360 p. (Rus.)

11. Ryzhkyn $V$. Y. Thermal power stations: Textbook for Universities / pod. red. V. J. Hyrshvelda. - M.: Energoatomizdat, 1987. - 328 p. (Rus.) 